\title{
Cunqueiro trovador
}

\begin{abstract}
$A^{1}$ lvaro Cunqueiro nace en Mondoleño, provincia de lugo, el 22 de A diciembre de 1911, en su amada y terrenal Galicia, no lejos del mar, al que con la fidelidad sonora del oleaje y en el arbolado nombre de la Fábula, cantará a lo largo de su vida, para morir en 1982.

Personaje proteico de la vida y de las letras, gran poeta y narrador, dramaturgo, gastrónomo y mitógrafo, lo mismo que fabulador de mitos, leyendas y fábulas propios, Cunqueiro zarpa de una vastísima erudición que contempla los hechos de las más diversas culturas y horizontes, para así recrearlos en un ejercicio libérrimo de la imaginación, fasto que es fuerza hermanada y primigenia del cuerpo que reclama la soberanía del espíritu -presencia de lo real y más concreto en el hombre, puesto que singular por irrepetible-, y a través de la cual el hombre se salva a sí propio al rescatarse del círculo infernal e intercambiable de las cosas inertes. Trovador de añejas y remozadas cantigas, hombre de letras de una curiosidad puntual y minuciosa que jamás pierde el conjunto del paisaje, conocedor de antiguas tradiciones y, como él mismo lo sabía, de los grandes temas de nuestro tiempo, a otros viajaba para rescatar en ellos manojos de maravillas y así ofrecernos generosamente su aroma. Poeta de raza y estripe solariegas, de él y de su literatura podría decirse que manifiestan una enjundia y una exultación de raigambre espinoziana, una alegría que si bien no desconoce la nostalgia y la melancolía, se resuelve como la de quien afirma el destino de una manifestación gozosa y constante del carácter, tanto como la de aquel otro, el mismo, que se rebela contra lo que se pretende fatal, e inexorablemente inexorable.

Y si el hombre habla porque es mortal, y si todos los hombres son concientes, en mayor o menor grado, de su condición efímera y de las tristes pasiones, y por lo tanto y en virtud de sus obras tratan de
\end{abstract}


conjurarlas, en Álvaro Cunqueiro la poesía -esa perfección inútil de la belleza, como la definiera otro gran poeta que también loara a la mar-es entonces la manifestación ejemplar del poeta, del héroe que conjura la muerte con el tesoro resplandeciente del lenguaje y de sus palabras cuando, al cantar desde su solitaria intimidad, canta por lo alto y solidariamente para todos. Así, como el que más, Álvaro Cunqueiro.

Hay que agradecer la paciente y cuidadosa labor de recolección de los textos que a lo largo de muchos años Cunqueiro public6 en el periódico Faro de Vigo, del que fue director, y en otros muchos periódicos y revistas. Debemos esta labor a Néstor Luján, quien prologó y se hizo cargo de la edición del libro Fábulas y leyendas de la mar (1982), y al poeta César Antonio Molina, quien asimismo prologó y seleccionó los textos que componen Tesorosyotras magias (1984), Viajes imaginarios y reales (1986) y Los otros caminos (1988), texto este último, que extrañamente aparece sin prólogo alguno, seguramente por cuestiones editoriales. Los textos antes mencionados aparecieron bajo el sello de la editorial Tusquets, Barcelona. En México además pueden conseguirse los títulos Las mocedades de Ulises, editado originalmente por Ed. Destino y reeditado por la Espasa-Calpe en la Colección Austral; también Viaje por los montes y chimeneas de Galicia (Caza y cocina gallegas), escrito con José María Castroviejo y publicado asimismo por la Editorial EspasaCalpe en la colección mencionada (núm. 1318). También debemos a César Antonio Molina la espléndida Antología poética, en versión bilingüe, de la poesía de Álvaro Cunqueriro (Plaza y Janés, 1983, Barcelona), poemas traducidos por el propio Molina, quien los acompaña de un excelente prólogo suyo en el que se discierne con inteligencia el sitio que ocupa la poesía de Cunqueiro en los ámbitos de la poesía gallega y castellana. Cabe mencionar que de la vasta bibliografía de Cunqueiro, muchos de sus textos escritos en castellano han sido publicados por la espléndida editorial Destino y que, por otra parte, la editorial Galaxia, que tanto ha hecho por la cultura de Galicia en tiempos difíciles prepara desde hace tiempo las obras completas del escritor gallego. Es de justicia asimismo mencionar que entre nosotros el primero que señaló la importancia de la literatura cunqueriana fue el excelente poeta Francisco Cervantes. El lector curioso puede consultar La gaceta del Fondo de Cultura 
Económica (núm. 162, junio de 1984), en la que aparecen dos poemas traducidos $y$ anotados por el propio Cervantes.

Por último. Los tres poemas en prosa que el lector tiene en sus manos curiosamente no aparecen en ninguna antología conocida por quien esto escribe. Si hemos de creer a César Antonio Molina, Cunqueiro no guardó copia de muchos de sus textos; no es improbable entonces que tales poemas hayan sido leídos a la fecha sólo por algunos afortunados. Los poemas en cuestión fueron publicados en marzo de 1956, en el número 51 de la revista madrileña Poesía española. Y basta. Asómese el lector a la poesía del gran escritor gallego.

Roberto Vallín*

\section{LAS MANZANAS DE ORO \\ Canción de amor del ladrón de ganado}

Entre los sfi, los jóvenes pastores se declaran el amor por medio de refranes y veladas alusiones, $y$ cuando se creen aceptados, ellos rompen una larga vara de omoé.

Frobenius

Una pastora está con sus ovejas en la colina de Kumí. Si yo fuese pastor no temería acercarme, y le preguntaría: $6 \mathrm{Ha}$ llovido en Kumr?

Ella me respondería: "Ha llovido en Kumi, y ahora la hierba es tan suave como mis mejillas."

Yo me apoyaría en la larga vara de omoé y le preguntaría cuántas ovejas tiene su rebaño.

Ella me respondería: "De la leche de mis ovejas podrían beber seis cuencos el padre, la madre y siete hijos varones, $y$ aún haría cada día un queso para el tiempo de las lluvias. Con su lana podría tejer dos cinturones para cada uno, y un ceñidor para mí, cuando dejase de amamantar al más pequeno."

\footnotetext{
- Poeta y ensayista
} 
Yo rompería entonces en dos pedazos mi vara de omoé, y le daría a ella el más corto, diciéndole: "Mis años pasarán al lado de mi esposa como el agua del río pasa, acariciando la orilla." Ella me respondería: "La esposa estará quieta, mi señor, como la orilla que ve pasar las aguas, y como la piedra del hogar, siempre encendido en la casa del rey."

Pero como no soy pastor, y sí un guerrero fan, ladrón de ganado, y tengo en la espalda tatuado un león, no puedo subir a Kumí, a hablar con la pastora. Gritaría de terror al verme, pobre de mí.

\section{BURGOS, CABEZA DE CASTILLA}

E vino a Burgos el rey don Pedro, efizo justicia Crónica de Don Pedro I El Cruel.

Las herradas puertas del castillo se abren lentamente. El gentil trompetero ha dado la señal. El señor rey de Castilla está sentado en su trono bermejo. El difunto señor rey de Castilla. Cualquiera. ¿Quién recuerda sus nombres?

Entre dos losas del atrio nacieron unas hierbas, y por el áspero muro se encarama un rosal. El asesino se detiene un instante contemplándolo, escogiendo la rosa que le gustará llevar a la oreja cuando lo ahorquen.

El señor rey de Castilla va a juzgar a un hombre. Es un soldado. Bebió espeso vino tinto en el cuenco de las manos de una novicia, y así que hubo bebido, con la pesada espada, partió en dos el dulce vaso.

- Yo pagaré el vaso, señor, dice el soldado, arrodillándose.

- Verted vino en el cuenco de sus manos, dice el rey.

Pero ya no queda ni una gota de vino en Castilla. $Y$ el cuenco de las manos del soldado ha de llenarse con su sangre.

Bebe pausadamente el señor rey de castilla. El difunto señor rey de Castilla. Cualquiera. ¿Quién recuerda sus nombres? Cuando el sediento rey termina de beber, el soldado está muerto. También está muerto hace muchos, muchos años, el 
rey de Castilla. El ciego que canta el romance pisa con sus zuecos la hierba que nació entre dos losas del atrio.

\section{EL PRINCIPE QUE MURIO CON SUS TESOROS EN EL CORAZÓN}

-¿Qué llevas en el corazón?, le preguntaron a un principe samani, moribundo.

- Un verano en los altos llanos, respondio

Crónica de Ibn al Muqaffa.

Enterradme con la alondra mañanera en la caja roja de mi corazón. Poned también en mi corazón el rocío de la hierba en el alba, y la hierba misma, y la brisa que la mece. Poned también en mi corazón la sombra de la acacia pérsica a mediodía, y la fuente que canta en la sombra, y las palomas que se arrullan en los húmedos flancos del brocal.

Poned en mi corazón la enorme copa dorada de la tarde, y el faisán que vuela por sus bordes, y mi flecha que sigue al faisán y lo hiere. Poned la noche, la muchacha que trae la jarra de leche recién ordeñada, la hoguera ante la tienda y el músico ciego que a su amor templa el rabé.

Poned también en mi corazón la sonrisa de la doncella, el vaso de plata lleno de agua de rosas hasta derramar, el can que ladra en el silencio nocturno...

Pero no pongáis, iay de mí!, en mi corzón, mi caballo bayo, que entonces no podría descansar. ¿Cómo vencería la muerte en mi corzón el deseo de cabalgar por los altos llanos, en las mañanas frías? 